\title{
PROPOSED STRATEGIES FOR DWPF MELTER OFF-GAS SURGE CONTROL
}

A. S. Choi

June 2004

Immobilization Technology Section

Savannah River National Laboratory

Savannah River National Laboratory

Aiken, SC 29808

Prepared for the U.S. Department of Energy Under Contract Number DEAC09-96SR18500

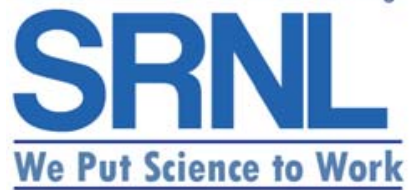


This document was prepared in conjunction with work accomplished under Contract No. DE-AC09-96SR18500 with the U. S. Department of Energy.

\section{DISCLAIMER}

This report was prepared as an account of work sponsored by an agency of the United States Government. Neither the United States Government nor any agency thereof, nor any of their employees, makes any warranty, express or implied, or assumes any legal liability or responsibility for the accuracy, completeness, or usefulness of any information, apparatus, product or process disclosed, or represents that its use would not infringe privately owned rights. Reference herein to any specific commercial product, process or service by trade name, trademark, manufacturer, or otherwise does not necessarily constitute or imply its endorsement, recommendation, or favoring by the United States Government or any agency thereof. The views and opinions of authors expressed herein do not necessarily state or reflect those of the United States Government or any agency thereof.

This report has been reproduced directly from the best available copy.

Available for sale to the public, in paper, from: U.S. Department of Commerce, National Technical Information Service, 5285 Port Royal Road, Springfield, VA 22161, phone: (800) 553-6847, fax: (703) 605-6900

email: orders@ntis.fedworld.gov

online ordering: http://www.ntis.gov/help/index.asp

Available electronically at http://www.osti.gov/bridge

Available for a processing fee to U.S. Department of Energy and its contractors, in paper, from: U.S. Department of Energy, Office of Scientific and Technical Information, P.O. Box 62, Oak Ridge, TN 37831-0062,

phone: (865)576-8401,

fax: (865)576-5728

email: $\underline{\text { reports@ adonis.osti.gov }}$ 
WSRC-TR-2004-00156

Revision 0

Key Words: DWPF, Off-Gas Surge, Controller Tuning

Retention: Permanent

\title{
PROPOSED STRATEGIES FOR
} DWPF MELTER OFF-GAS SURGE CONTROL

\author{
A. S. Choi
}

June 2004

Immobilization Technology Section

Savannah River National Laboratory

Savannah River National Laboratory

Aiken, SC 29808

Prepared for the U.S. Department of Energy Under Contract Number DEAC09-96SR18500

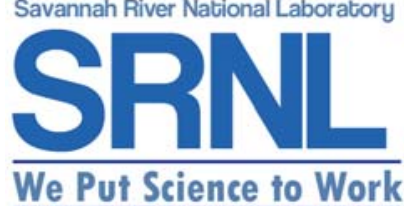


This page was intentionally left blank 


\section{EXECUTIVE SUMMARY}

The purpose of this work was to assess recent DWPF melter performance data and determine if the adverse impacts of off-gas surges on the glass pouring operation could be lessened by implementing appropriate DCS hardware and/or software changes. However, the purpose of this work was not to pin down the sources of off-gas surging and mitigate them in the first place. Two sets of melter data were reviewed during the course of this work, each spanning a period of 4 hours before and after the installation of the glass pump on 2/10/04 near the end of the Sludge Batch 2 (SB2) campaign.

The conclusions drawn from the review of data include:

- The intensity of off-gas surging and subsequent pressure spikes appeared to have gotten higher with the glass pump in operation than without the glass pump.

- The measured dead times of the melter pressure control (PIC3521), exhauster speed control (FIC3691) and melter-pour spout differential pressure control (PDIC3526) loops in response to off-gas surges of varying intensities ranged from 2 to 6 seconds.

- These inherent dead times represent a significant setback for controlling off-gas surges that typically last for 5 to 10 seconds. Furthermore, delayed responses by the FIC3691 and PDIC3526 loops are actually making the recovery process more difficult.

- The feed forward control is not a viable option, since the load variable, i.e., off-gas surges, neither can be measured nor predicted; only its impact can be measured as the PI3521.

Based on the results of this review, it is hypothesized that maintaining as small fluctuations as possible not only in the melter-pour spout differential pressure (PDI3526) but the pour spout pressure (PI3527) itself is crucial to minimizing the pour stream waiver and thus lengthening the duration between successive pour spout cleanouts. It is proposed that the following changes be made to the current off-gas control strategy:

- Rely exclusively on the PIC3521 loop for the control of off-gas surges and detune the FIC3691 loop to avoid excessive melter pressure oscillations during the recovery process.

- To attenuate the intensity of pressure spikes, look for ways to reduce the dead time of the PIC3521 loop.

- Increase the FIC3691 set point from its current value of 500 to $\sim 800 \mathrm{lb} / \mathrm{hr}$ mainly for the attenuation of large melter pressure spikes above +2 inches $\mathrm{H}_{2} \mathrm{O}$.

- Discontinue the melter-pour spout differential pressure control by decoupling the PT3521 from the PDIC3526 loop. 
- Instead, control the pour spout pressure (PI3527) at the predetermined set points for pouring and non pouring operations by modulating the pour spout control air valve.

- Perform a detailed simulation study using the existing off-gas model to identify the exact causes for the pour spout pressure oscillations that occur during the initial stages of canister filling.

This study further investigated if the current location of the pour spout pressure transmitter (PDT3527), which is several feet downstream of the pour spout control air entry point, would adversely impact the glass pouring operation during a transient such as off-gas surging. The actual pour spout pressures measured recently using a portable pressure gauge were approximately 1 inch $\mathrm{H}_{2} \mathrm{O}$ higher than those measured at the current PDT3527 location during a steady state. However, it remained uncertain whether the actual melter-pour spout differential pressure with the current PDT3527 input would fluctuate more during a transient than it would had the PDT3527 been located upstream of the control air entry point as close to the pour spout as practically possible.

In order to resolve this uncertainty, the existing off-gas model was expanded to include both the current and ideal PDT3527 locations and the revised model was then run to simulate a +0.4 inch $\mathrm{H}_{2} \mathrm{O}$ pressure surge as a reference transient event, when the PDIC3526 loop was fed with the two different PDT3527 inputs. The model results showed that throughout the surge duration the amplitudes of fluctuations in both the melter-pour spout differential pressure and the pour spout pressure were in essence identical in both cases, which confirms that the differential pressure control based on the current PDT3527 location is not likely to adversely impact the pouring operation more so than when the PDT3527 is located inside the pour spout/bellows assembly. 


\section{TABLE OF CONTENTS}

EXECUTIVE SUMMARY iv

LIST OF FIGURES vii

LIST OF TABLES

LIST OF ACRONYMS

1.0 INTRODUCTION AND BACKGROUND

2.0 DATA ANALYSIS

vii

2.1 Impact of Glass Pump on Off-Gas Surging

viii

2.2 Impact of Glass Pump on Differential Pressure

2.3 Dead Times

2.4 Optimal Control of Pour Stream Waiver

2.4.1 Melter Pressure vs. Differential Pressure

2.4.2 Pour Spout Pressure vs. Differential Pressure

2.4.3 Optimal Pressure Control

3.0 COMPUTER SIMULATION

3.1 Model Input

3.2 Model Results

4.0 CONCLUSIONS

5.0 RECOMMENDATIONS/PATH FORWARD 


\section{LIST OF FIGURES}

Figure 1. Impact of Glass Pump on Melter Pressure Spikes.............................................. 3

Figure 2. Impact of Glass Pump on Melter-Pour Spout Differential Pressure Spikes............ 4

Figure 3. Impact of Dead Times on Melter Pressure.......................................................... 5

Figure 4. Melter and Melter-Pour Spout Differential Pressure Profiles During Post Glass

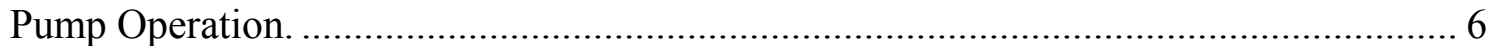

Figure 5. Pour Spout and Melter-Pour Spout Differential Pressure Profiles........................ 7

Figure 6. Melter-Pour Spout Differential Pressure Control during a -2 inch $\mathrm{H}_{2} \mathrm{O}$ Surge With No Glass Pump.

Figure 7. Comparison of Melter-Pour Spout Differential Pressures during a -2 inch $\mathrm{H}_{2} \mathrm{O}$ Surge with Current and Modified PDIC3526............................................................. 10

Figure 8. Melter-Pour Spout Differential Pressure Control during a +0 inch $\mathrm{H}_{2} \mathrm{O}$ Surge With Glass Pump.

Figure 9. Comparison of Melter-Pour Spout Differential Pressures during a +0 inch $\mathrm{H}_{2} \mathrm{O}$

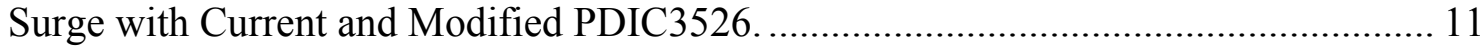

Figure 10. Melter-Pour Spout Differential Pressure Control during a +5 inch $\mathrm{H}_{2} \mathrm{O}$ Surge

With Glass Pump. ......................................................................................... 12

Figure 11. Comparison of Melter-Pour Spout Differential Pressures during a +4 inch $\mathrm{H}_{2} \mathrm{O}$

Surge with Current and Modified PDIC3526........................................................... 13

Figure 12. Calculated Profiles of PIC3521, FIC3691 and SIC3585 During +0.4 inch $\mathrm{H}_{2} \mathrm{O}$

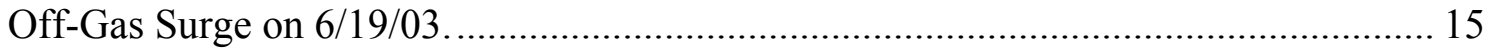

Figure 13. Calculated Differential Pressure Profiles With Current PDT3527 Input............ 17

Figure 14. Calculated Differential Pressure Profiles With Revised PDT3527 Input. .......... 17

Figure 15. Calculated Profiles of Differential and Pour Spout Pressures with Current

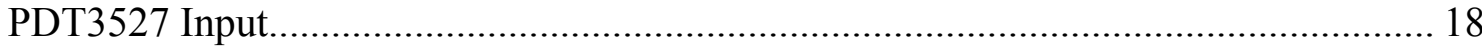

Figure 16. Calculated Profiles of Differential and Pour Spout Pressures with Revised

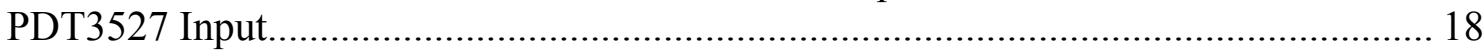

\section{LIST OF TABLES}

Table 1. Measured Dead Times of DCS Loops During Off-Gas Surges.............................. 5

Table 2. Comparison of DCS Data and Model Output for 6/19/03 Melter Run................... 14 
WSRC-TR-2004-00156

Revision 0

\title{
LIST OF ACRONYMS
}

\author{
DCS \\ Distributed Control System \\ DWPF \\ Defense Waste Processing Facility \\ SB \\ Sludge Batch
}


WSRC-TR-2004-00156

Revision 0

This page intentionally left blank. 


\subsection{INTRODUCTION AND BACKGROUND}

Off-gas surging is inherent to the operation of slurry-fed melters. Although the melter design and the feed chemistry are both known to significantly affect off-gas surging, the frequency and intensity of surges are in essence unpredictable. In typical off-gas surges, both condensable and non condensable flows spike simultaneously. Condensable or steam surges have been observed to occur as the boiling water layer occasionally falls into the crevices of the cold cap or flows over the edges of the cold cap, thereby coming in contact with the melt surface. The resulting steam surges can pressurize the melter considerably and, therefore, are responsible for the bulk of pressure transients that propagate throughout the off-gas system. The non condensable surges occur as the calcine gases that have been accumulating within the cold cap finally build up enough pressure to be released through the temporary openings of the cold cap.

The analysis of off-gas data has shown that over $90 \%$ of the gas released during a surge is due to steam. ${ }^{1}$ Therefore, it is essential to have a large inventory of water in the cold cap for any significant pressure spikes to occur. With the Melter 2 vapor space temperature typically running at $\sim 720{ }^{\circ} \mathrm{C}$, the water layer in the cold cap will quickly evaporate once the feeding stops, and the potential for any large pressure spikes should practically cease to exist. The analysis also showed that large pressure spikes well above +2 inches $\mathrm{H}_{2} \mathrm{O}$ cannot occur under the steam surge scenarios described above. More severe conditions should prevail and one such condition would be that the feed materials form a mound with a growing lake on top, while the melt below remains very fluidic due to its low viscosity, thus resulting in greater movements both in the lateral as well as vertical directions. Once the mound begins to grow, its rate should accelerate, since the heat transfer rate to the upper regions of the cold cap is inversely proportional to the cold cap thickness. Then, when the mound reaches some critical mass, it may begin sink into the bulk melt or tip over, thereby creating a condition almost like a steam explosion.

Compared to previous melter runs, the intensity and frequency of off-gas surging in Melter 2 with the SB2 feed were much higher, which led to several power pours. It has been speculated that the lower viscosities of the SB2 melt ranging from 30 to 35 poise are most likely responsible for the cold cap instability and severe off-gas surging. The support for this speculation comes from the fact that since the recent introduction of the SB2/3 feed, the melt viscosity has been increased to near 50 poise, and both the intensity and frequency of off-gas surging have been significantly reduced. A comparison of limited dome heater power data also suggests that the cold cap coverage with the SB2/3 feed is higher, which seems to suggest that the current feed is spreading better than the SB2 feed did, thus resulting in a less tendency for mounding.

Regardless of whether the off-gas surging is impacted by the melt viscosity, feed spreadability or any other factors, the plant data have clearly shown that the frequency of the pour spout cleaning is proportional to the intensity of off-gas surging and the resulting pressure spikes. Therefore, in order to reduce the downtime and increase the overall glass production rate, the melter pressure spikes must be controlled within manageable amplitudes, and the purpose of this work was to determine if the attenuation of pressure spiking could be achieved by implementing appropriate DCS hardware and/or software changes. However, the purpose of this work was not to infer the sources of off-gas surging or to mitigate them in the first place. 
A computer simulation study was also performed during this work to examine the impact of the pour spout pressure transmitter location on the melter-pour spout differential pressure control. In DWPF, the glass pouring operation is either initiated or terminated by changing the set point of the PDIC3526 control loop so as to increase or decrease, respectively, the differential pressure between the melter vapor space and the pour spout. However, the pour spout pressure is not currently measured inside the pour spout/bellows assembly. Instead, it is measured inside a 2inch pipe leading to the spout jet at a location several feet downstream of the pour spout control air entry point. The ideal location for the pressure transmitter (PDT3527) would be upstream of the control air entry point as close to the pour spout as practically possible. The actual pour spout pressures measured recently using a portable pressure gauge were approximately 1 inch $\mathrm{H}_{2} \mathrm{O}$ higher than the data taken at the current PDT3527 location during a steady state. However, it remained uncertain whether the actual melter-pour spout differential pressure with the current PDT3527 input would fluctuate more during a transient than it would had the PDT3527 been placed ideally, thereby adversely affecting the pouring operation.

In order to resolve this uncertainty, the existing off-gas model was expanded to include both the current and ideal PDT3527 locations and further tuned using the latest melter off-gas performance data. The revised model was then run to simulate a +1 inch $\mathrm{H}_{2} \mathrm{O}$ pressure surge as a reference transient event, when the PDIC3526 loop was fed with the two different PDT3527 inputs. The results of model runs were then compared to determine if the amplitude of fluctuations in both the melter-pour spout differential pressure and the true pour spout pressure were any different in the two cases.

\subsection{DATA ANALYSIS}

In February 2004, the glass pump was lowered into the melt pool in order to boost the glass production rate. In this work, the off-gas data collected both before and after the installation of the glass pump were analyzed to assess its impact on the overall system performance, including the off-gas surging potential. Specifically, the pre glass pump operation data were collected between 20:00 and 24:00 hours on 2/9/04, while the post glass pump operation data were collected between 20:00 and 24:00 hours on 2/12/04. During these times, the melter was fed with the SB2 feed. The analysis was focused on three critical DCS loops; PIC3521 (melter pressure), FIC3691 (exhauster speed), and PDIC3526 (melter-pour spout differential pressure).

\subsection{Impact of Glass Pump on Off-Gas Surging}

The melter pressure spikes measured during each 4-hour period before and after the glass pump installation are compared in Figure 1. It appears that the frequency of pressure spikes was higher during the pre glass pump operation but the intensity or the amplitude of pressure fluctuations from the set point of -5 inches $\mathrm{H}_{2} \mathrm{O}$ was smaller than during the post glass pump operation. For example, the melter pressure varied from -8 to -2 inches $\mathrm{H}_{2} \mathrm{O}$ or \pm 3 inches $\mathrm{H}_{2} \mathrm{O}$ from the set point during the pre glass pump operation, while it varied from -10 to +5 inches $\mathrm{H}_{2} \mathrm{O}$ or $> \pm 5$ inches $\mathrm{H}_{2} \mathrm{O}$ from the set point during the post glass pump operation. Although not included in this report, comparison of the more recent off-gas data collected over a much wider time span than 4 hours also revealed the same trend seen in Figure 1; the amplitude of melter pressure spikes was higher with the glass pump in operation than without the glass pump. 


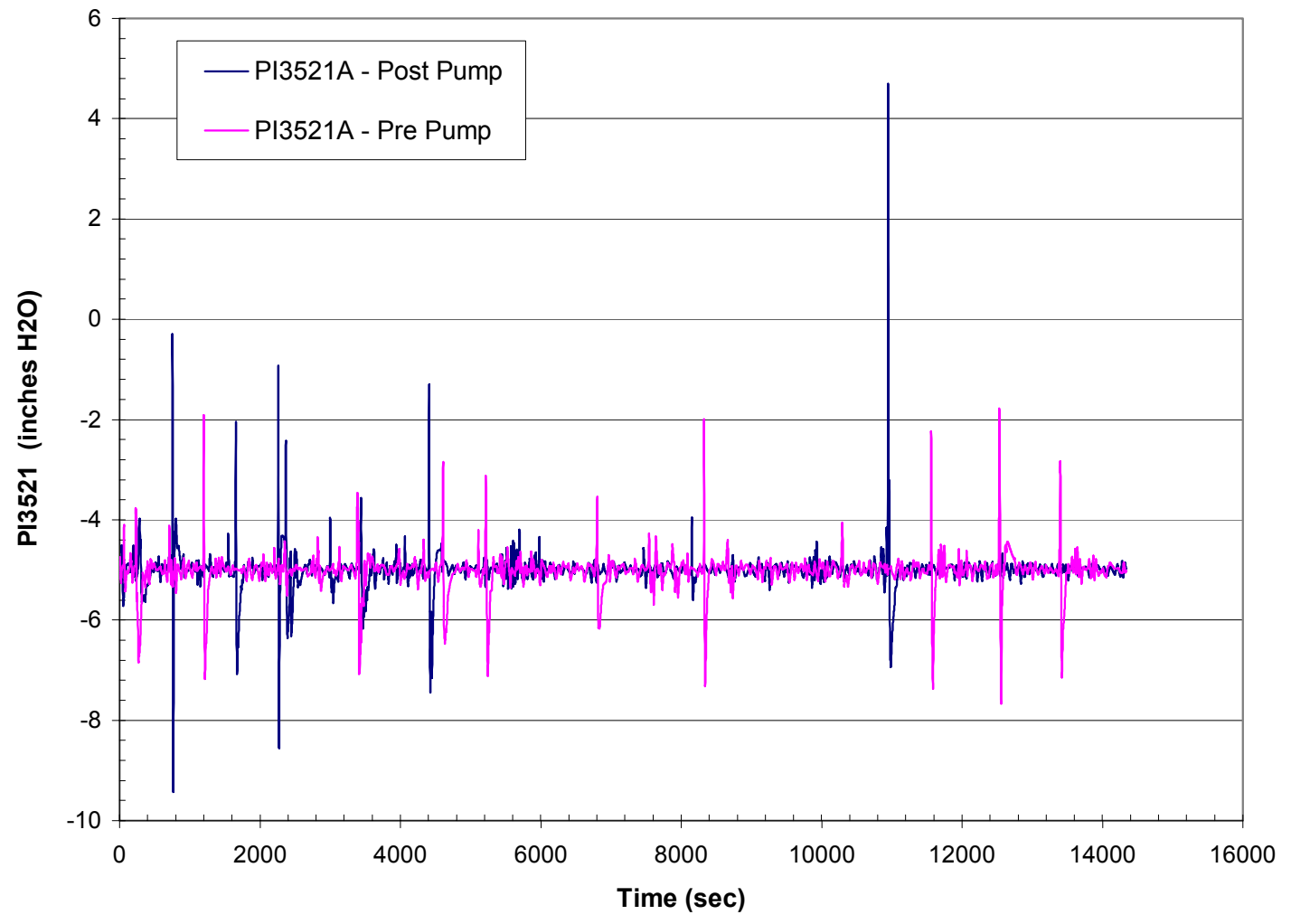

Figure 1. Impact of Glass Pump on Melter Pressure Spikes.

\subsection{Impact of Glass Pump on Differential Pressure}

The melter-pour spout differential pressure spikes measured during the pre and post glass pump operations are compared in Figure 2. As with the melter pressure, the amplitude of differential pressure fluctuations from its set point of -5 inches $\mathrm{H}_{2} \mathrm{O}$ during the pouring operation was larger with the glass pump in operation than without the glass pump. For example, the differential pressure varied from -8 to -1 inch $\mathrm{H}_{2} \mathrm{O}$ or \pm 4 inches $\mathrm{H}_{2} \mathrm{O}$ from the set point during the pre glass pump operation, while it varied from -15 to above 0 inch $\mathrm{H}_{2} \mathrm{O}$ or $> \pm 5$ inches $\mathrm{H}_{2} \mathrm{O}$ from the set point during the post glass pump operation.

Taken together with the trend seen in Figure 1, it may then be concluded that while the glass pump promotes better mixing of the melt pool, it also increases the likelihood of off-gas surging and subsequent pressure spiking. It has been observed that the higher the amplitude of pressure spikes, the greater the tendency for the pour stream to waiver and the pour spout to get plugged. The frequency of pressure spikes is less important as long as the amplitude remains low, e.g., the peak melter pressure less than -2 inches $\mathrm{H}_{2} \mathrm{O}$ or so. Therefore, it may be argued that with all other operating conditions being equal, continued operation of the glass pump will likely lead to a greater tendency for pour spout plugging than operation without the glass pump. 
Increased off-gas surging also means a higher rate of particulate carryover in the melter exhaust, and much of the large entrained particulates $(>\sim 10 \mu \mathrm{m})$ will be scrubbed out at the quencher. Since the steam flow to the Steam Atomized Scrubbers (SAS's) is currently valved out, the remaining fine particulates will then be collected at the HEME and HEPA. Therefore, it is anticipated that the HEME and/or HEPA filters would need to be changed out more frequently with the glass pump in operation.

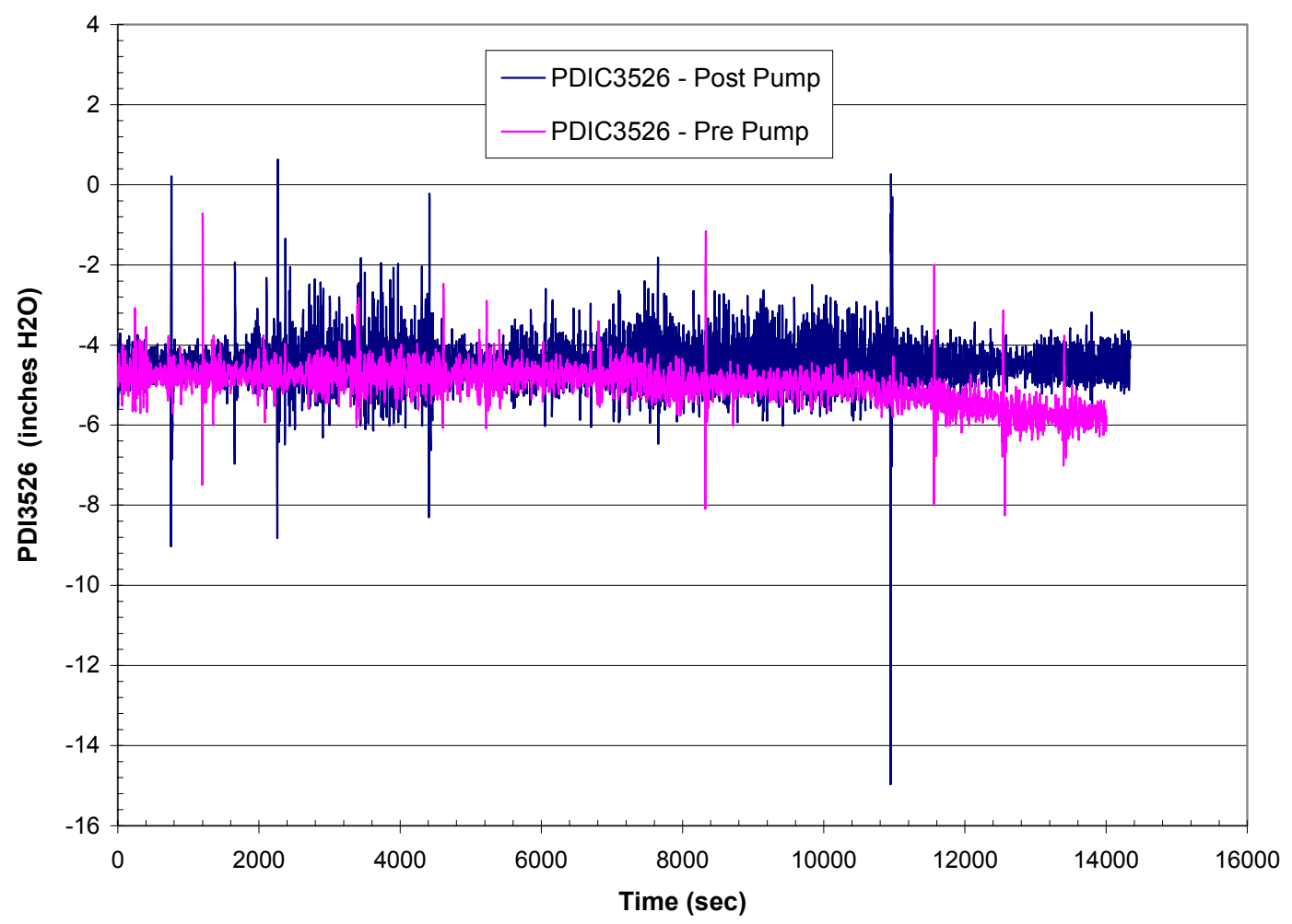

Figure 2. Impact of Glass Pump on Melter-Pour Spout Differential Pressure Spikes.

\subsection{Dead Times}

The transportation lags in the off-gas system are negligible compared to the instrumentation lags occurring in various components of the DCS loops such as transmitters, controllers and valves. The estimated dead times for the three main control loops are given in Table 1 along with the measured surge durations, which are defined as the time it takes for the melter pressure to reach the peak value from its initial steady state value. From the standpoint of controlling the melter pressure spikes, the effective dead time for the exhauster speed control loop is then the sum of the individual dead times for the PIC3521 and FIC3691 loops. The effective dead times thus estimated for the exhauster speed control loop ranged from 5 to 8 seconds, which are comparable to the surge durations shown in Table 1. This means that by the time the exhauster begins to accelerate as a result of the FIC3691 loop action, the melter pressure may already be at or past its peak, thereby actually making the recovery process more difficult than without any control. 
WSRC-TR-2004-00156

Revision 0

Table 1. Measured Dead Times of DCS Loops During Off-Gas Surges.

\begin{tabular}{|c|c|c|c|c|c|c|}
\hline \multirow{2}{*}{ Operation } & \multirow{2}{*}{ Date, Time } & \multirow{2}{*}{$\begin{array}{c}\text { Surge } \\
\text { Duration }\end{array}$} & $\begin{array}{c}\text { Peak Melter } \\
\text { Pressure }\end{array}$ & \multicolumn{3}{|c|}{$\begin{array}{c}\text { Dead Time } \\
(\mathrm{sec})\end{array}$} \\
\cline { 5 - 7 } & & $(\mathrm{sec})$ & $\left(\right.$ inch $\left.\mathrm{H}_{2} \mathrm{O}\right)$ & PIC3521 & FIC3691 & PDIC3526 \\
\hline Pre Pump & $2 / 9 / 0420: 19$ & 9 & -1.9 & 4 & 2 & 5 \\
\hline " & $2 / 9 / 0423: 28$ & 14 & -1.8 & 4 & 4 & 6 \\
\hline Post Pump & $2 / 12 / 0420: 12$ & 5 & -0.3 & 3 & 2 & 5 \\
\hline " & $2 / 12 / 0423: 02$ & 5 & +4.7 & 3 & 3 & 3 \\
\hline
\end{tabular}

What happens to the melter pressure when assisted by the FIC3691 loop during an off-gas surge is clearly shown in Figure 3. The effective dead time of the FIC3691 loop at 20:12 hour on 2/12/04 was estimated to be 5 seconds. Due to this dead time, the exhauster did not reach its maximum speed (SIC3585), until the melter pressure was already recovering from its peak value. In fact, the measured melter pressure was back down to -3.6 inches $\mathrm{H}_{2} \mathrm{O}$, when the exhauster reached its maximum speed of 940 RPM. As a result of this late exhauster speed controller kick-in, the melter pressure continued to fall to near -10 inches $\mathrm{H}_{2} \mathrm{O}$, before it finally recovered back to its set point of -5 inches $\mathrm{H}_{2} \mathrm{O}$. It should be noted that this large negative pressure swing is just as detrimental to maintaining a stable pour stream as that in the positive direction. Therefore, the best strategy to attenuate the melter pressure spikes during off-gas surges may be to rely on the PIC3521 alone without the assistance of the FIC3691.

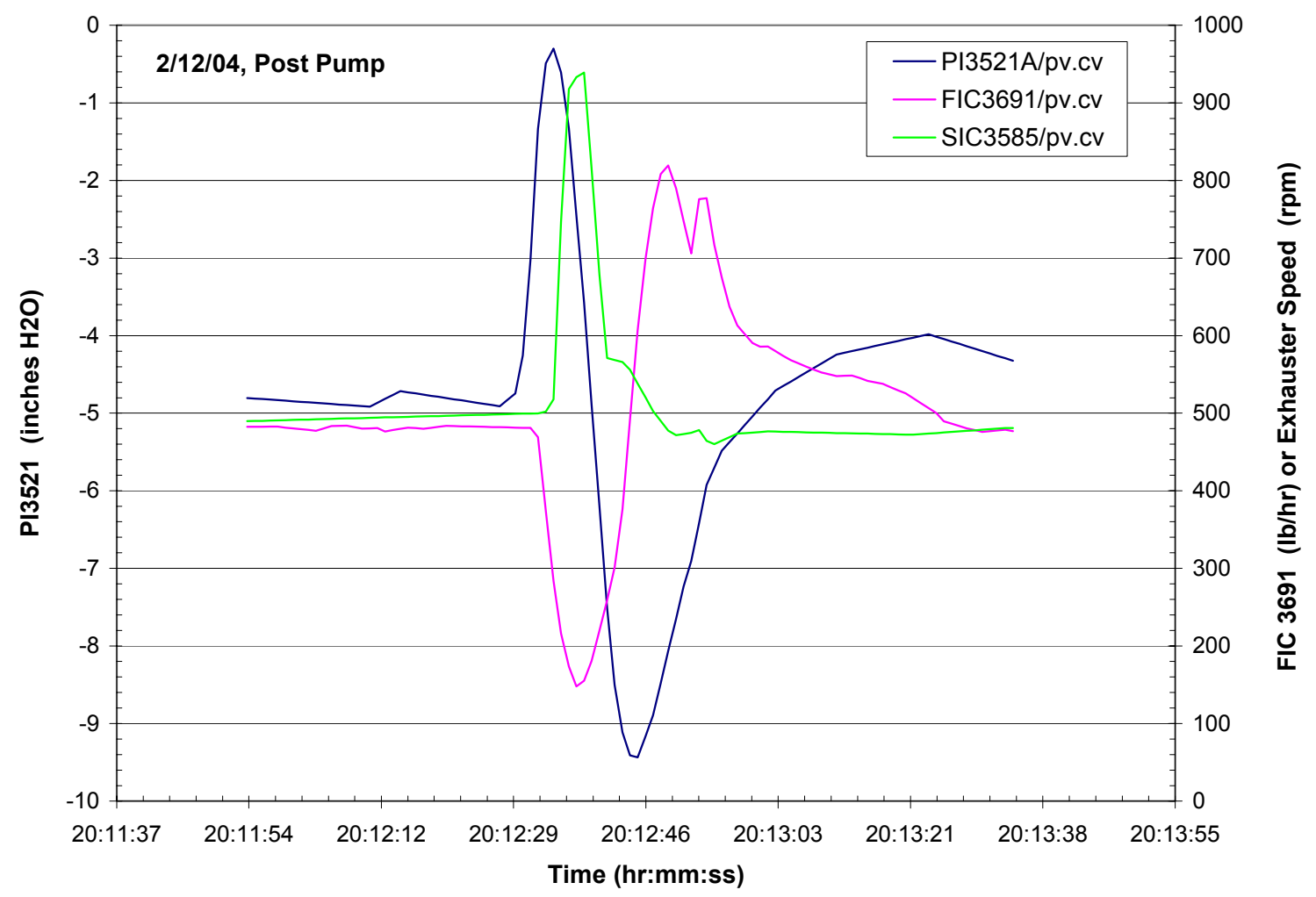

Figure 3. Impact of Dead Times on Melter Pressure. 


\subsection{Optimal Control of Pour Stream Waiver}

In this section, the plant data are further analyzed in regards to the question: Is the current glass pouring strategy based on the melter-pour spout differential pressure control the optimum way of controlling the pour stream waiver?

\subsubsection{Melter Pressure vs. Differential Pressure}

Regardless of whether the glass pump is used or not, all the large melter-pour spout differential pressure spikes coincided with the melter pressure spikes, as shown in Figure 4 for the post glass pump operation. This confirms that the large melter-pour spout differential pressure spikes, which may be part of the causes for the pour stream to waiver, are the direct result of off-gas surges. Close tracking of these two pressure spikes was expected, since the differential pressure (PDIC3526) is calculated in the DCS as the pour spout pressure (PI3527) minus the melter pressure (PI3521A), so any large change in either the PI3527 or PI3521A input will show up in the PDIC3526 output. It is, however, also noted in Figure 4 that the remaining small to medium differential pressure spikes are not correlated to the melter pressure spikes at all; the melter pressure remained relatively steady at other times, but the melter-pour spout differential pressure continued to oscillate. This suggests that those small to medium differential pressure spikes were due to the fluctuations in the pour spout pressure itself.

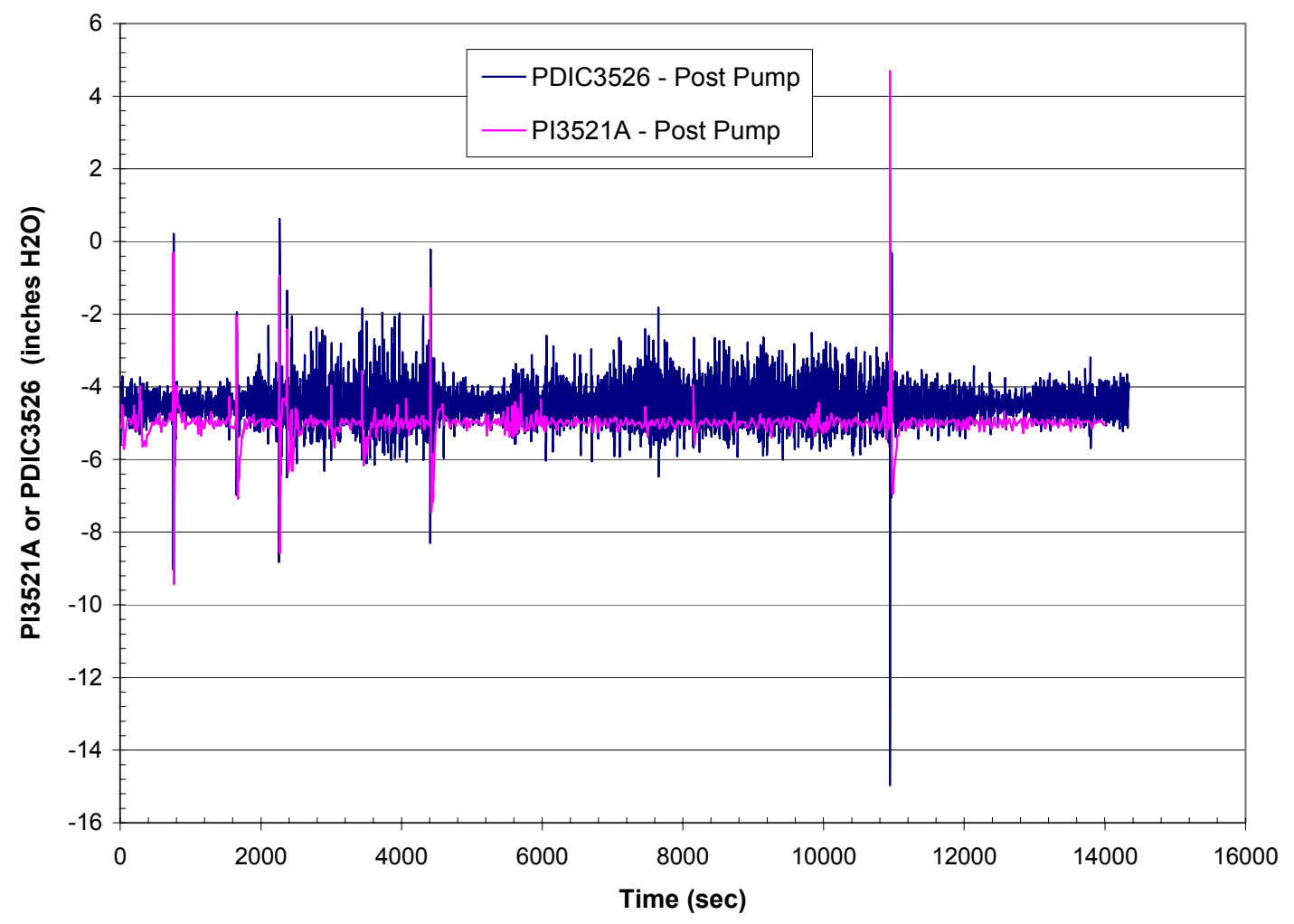

Figure 4. Melter and Melter-Pour Spout Differential Pressure Profiles During Post Glass Pump Operation. 


\subsubsection{Pour Spout Pressure vs. Differential Pressure}

Figure 5 shows that the small to medium melter-pour spout differential pressure spikes were indeed due to the fluctuations in the pour spout pressure regardless of melter pressure. In fact, the pour spout pressure profile is shown to track the differential pressure spikes of all amplitudes, including those large ones resulting from off-gas surges, and this was the result of the PDIC3526 loop action to maintain the differential pressure close to its set point. The pressure within the melter pour spout bellows has been observed to fluctuate by as much as \pm 2 to 4 inches $\mathrm{H}_{2} \mathrm{O}$, when glass pouring is initiated into an empty canister. ${ }^{2}$ These fluctuations occurred independent of off-gas surges and may well have been caused by a multitude of events working in sequence and/or simultaneously such as the heat up of air in the canister by the rising molten glass level, the subsequent increase in the pour spout pressure and decrease in the air inleakage into the pour spout/bellows assembly. ${ }^{3}$ In particular, the pour spout pressure should be quite sensitive to the variations in air inleakage, since the total suction by the spout jet is only on the order of $110 \mathrm{lb} / \mathrm{hr}$ under the current design, and well over $50 \%$ of that suction could be due to the air inleakage when the pour spout pressure is reduced to -10 inches $\mathrm{H}_{2} \mathrm{O}$ during pouring.

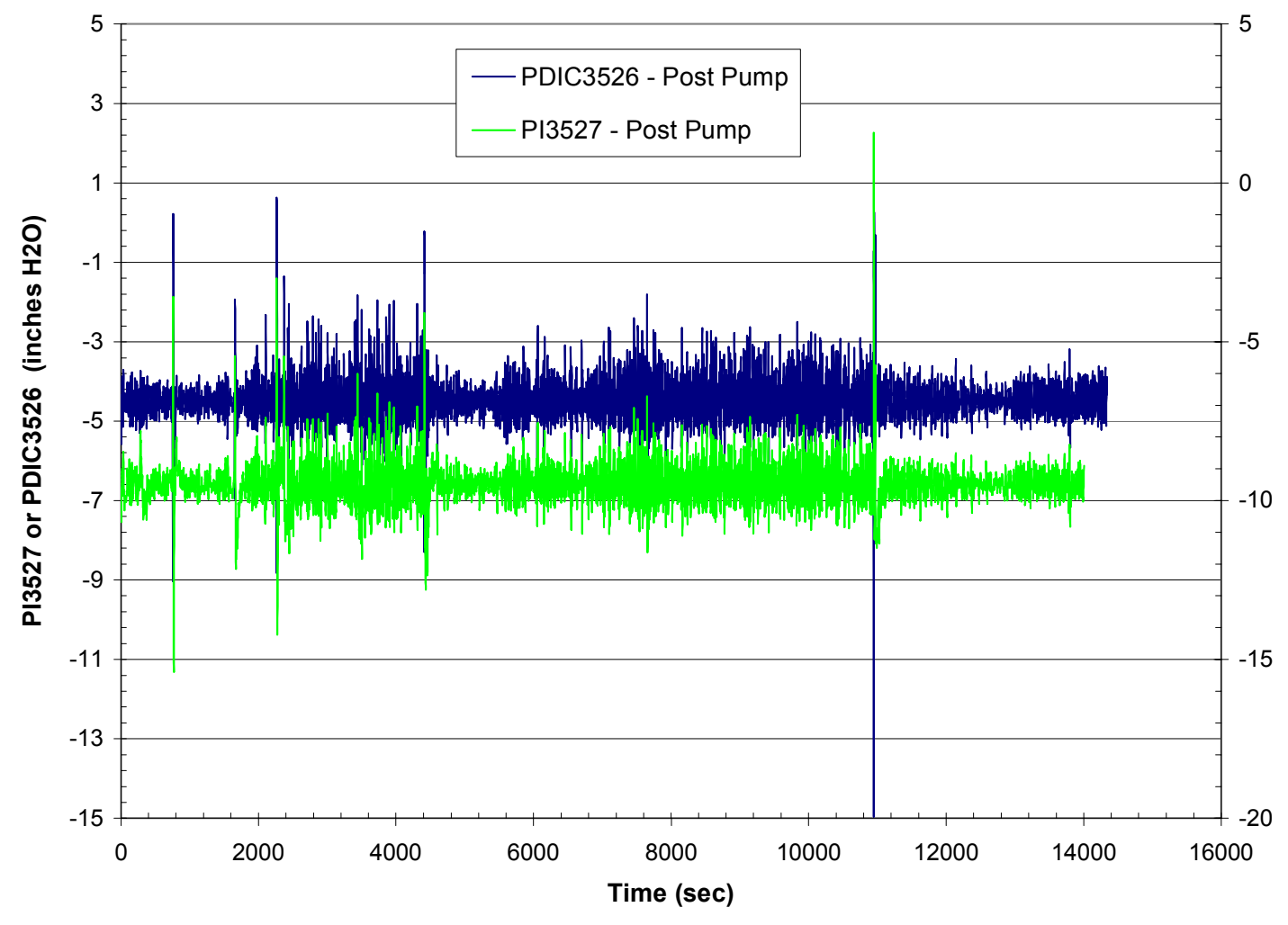

Figure 5. Pour Spout and Melter-Pour Spout Differential Pressure Profiles.

Therefore, the data have shown that significant melter-pour spout differential pressure spikes are caused by both off-gas surges and the inherent pour spout pressure oscillations during the initial stages of canister filling. The issue is then which of the two variables, the differential pressure or the pour spout pressure, needs to be controlled to reduce the tendency for the pour stream to waiver, which is the focus of the next section. 


\subsubsection{Optimal Pressure Control}

The pour rate increases with increasing melter-pour spout differential pressure. Here, increasing melter-pour spout differential pressure means that its value becomes more negative because it is calculated in the DCS as the pour spout pressure (PI3527) minus the melter pressure (PI3521A), while the pour spout pressure is always kept at a more negative value than the melter pressure during pouring. So, for example, if there is an off-gas surge, the differential pressure should fall to a more negative value and, as a result, the pour rate will increase. On the other hand, when the pour spout pressure increases sharply at a relatively constant melter pressure, the melter-pour spout differential pressure will then decrease or become less negative or even positive. The pour stream will slow down or even stop all together under these conditions.

Furthermore, it seems logical to argue that with all the relevant physical properties of glass being equal the tendency for the pour stream to waiver should depend on both the amplitude of pour spout pressure fluctuations and the pour rate. So, the pour stream should waiver more with increasing amplitude of pour spout pressure fluctuations, while it should waiver less with increasing pour rate due to increased inertia of glass. It is also noted that not only the amplitude but the direction of pour spout pressure fluctuations impact the pour stream waiver, since the latter directly affects the pour rate. That is, if the pour spout pressure increases sharply, e.g., in response to the PDIC3526 action, the melter-pour spout differential pressure will become less negative, and the pour rate will decrease, which makes the pour stream more prone to waiver. On the other hand, it the pour spout pressure falls from its nominal value during pouring, the differential pressure will become more negative, and the pour rate will increase, which makes the pour stream less prone to waiver.

Figure 6 shows how the melter-pour spout differential pressure control loop reacts to a small offgas surge with a peak melter pressure of -2 inches $\mathrm{H}_{2} \mathrm{O}$ during the pre glass pump operation. The measured melter-pour spout differential pressure is shown to fall immediately from its set point of -5 inches $\mathrm{H}_{2} \mathrm{O}$ at the onset of surge, but the pour spout pressure (PI3527) did not begin to rise to compensate for the melter pressure spike until 5 seconds later. This means that the initial drop in the differential pressure to its minimum and the resulting surge in the pour rate are inherent to the process due to the 5-second dead time of the PDIC3526 loop. Furthermore, just as the pour spout pressure finally began to rise in response to the differential pressure error signal, the melter pressure already reached its peak and was on its way down to its set point. As a result of this late kick-in of the PDIC3526 loop, the melter-pour spout differential pressure then swung sharply to the other direction and peaked at -1 inch $\mathrm{H}_{2} \mathrm{O}$, which would have nearly stopped the pour stream.

It is indeed surprising to find that even under such modest off-gas surge conditions as the peak melter pressure of -2 inches $\mathrm{H}_{2} \mathrm{O}$ the measured melter-pour spout pressure differential and the pour spout pressure itself fluctuated by as much as \pm 4 and \pm 5 inches $\mathrm{H}_{2} \mathrm{O}$, respectively. In order to see if these greater-than-expected pressure fluctuations were in part exacerbated by the 5second dead time of the PDIC3526 loop, the melter-to-pour spout differential pressure profile shown in Figure 6 was next re-calculated under the conditions where the PT3521 was de-coupled from the PDIC3526 loop, and the PDCV-3526 valve was modulated to maintain the PI3527 constant at the set point of near -10 inches $\mathrm{H}_{2} \mathrm{O}$. In doing so, the current control strategy for glass pouring is effectively shifted from maintaining a constant melter-to-pour spout differential pressure to maintaining a constant pour spout pressure. 


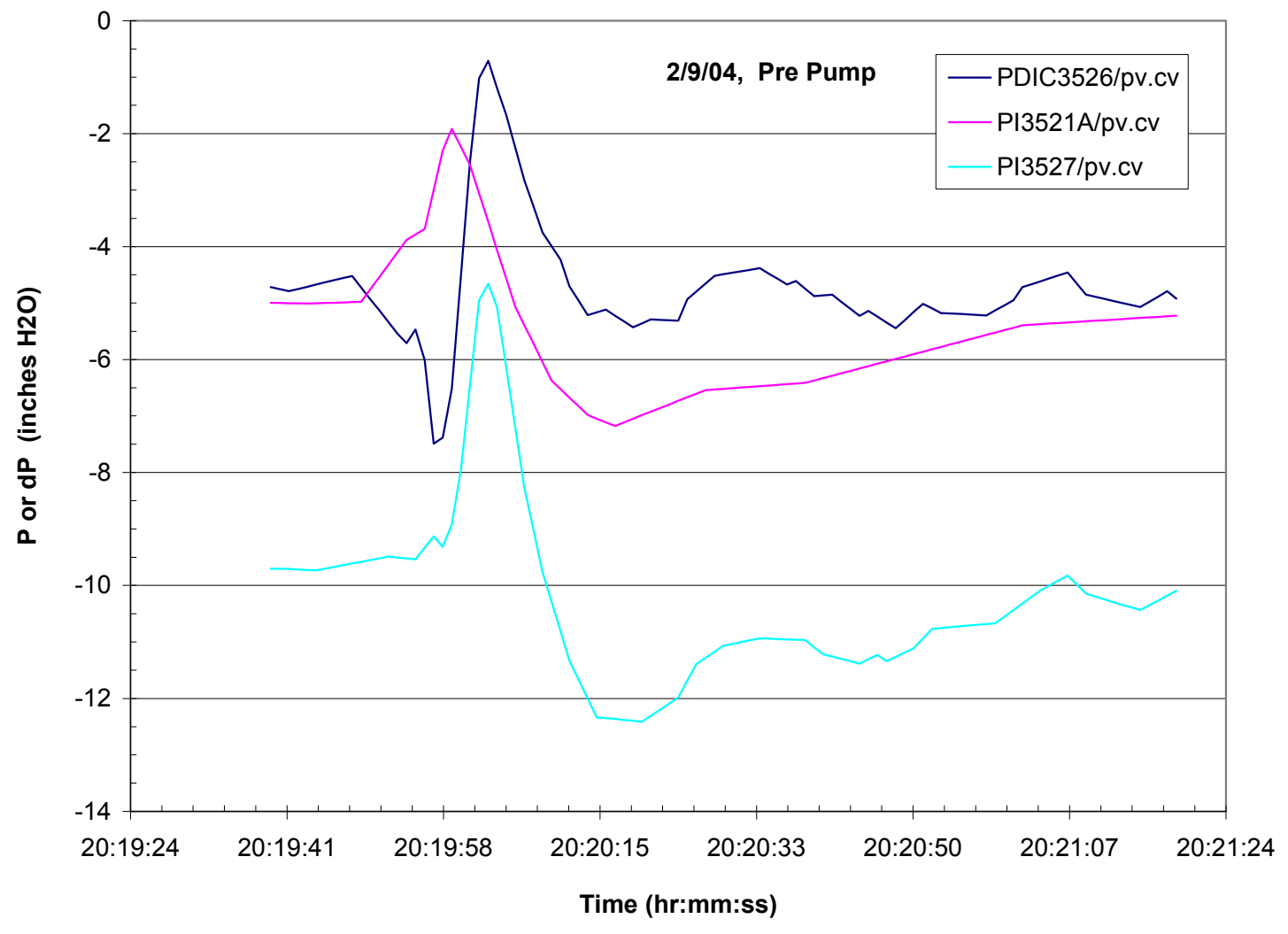

Figure 6. Melter-Pour Spout Differential Pressure Control during a -2 inch $\mathrm{H}_{2} \mathrm{O}$ Surge With No Glass Pump.

The new melter-pour differential pressure profile thus calculated under the constant pour spout pressure control mode is compared in Figure 7 with the measured profile under the current differential pressure control mode. The new differential pressure is shown to fall slightly more at the onset of surge but its peak value during the recovery step is considerably smaller than the measured data. Having a lower peak differential pressure is particularly important, since it means that the pour rate would not fall as much, so the pour stream would not be as prone to waiver in case of unexpected pressure oscillations. However, more important is the underlying assumption that the pour spout pressure remains constant under the new control mode, which should greatly reduce the tendency for the pour stream to waiver when compared to the large pour spout pressure fluctuations seen in Figure 6 under the current differential pressure control mode.

Considering the large pressure oscillations observed when glass pouring is initiated into an empty canister, ${ }^{2}$ maintaining the pour spout pressure constant as assumed in Figure 7 will not be achievable in reality, unless the inherent instrument dead time is virtually eliminated. However, with a dedicated controller, it should be possible to significantly reduce the large pour spout pressure peak seen in Figure 6, and the amplitude of the resulting PI3527 oscillations would be more manageable. As a comparison, the current PDIC3526 loop is designed to respond to any changes in both the melter and pour spout pressures. So, in case of large melter pressure spikes, the pour spout pressure is bound to vary wildly regardless of the dead time. 
WSRC-TR-2004-00156

Revision 0

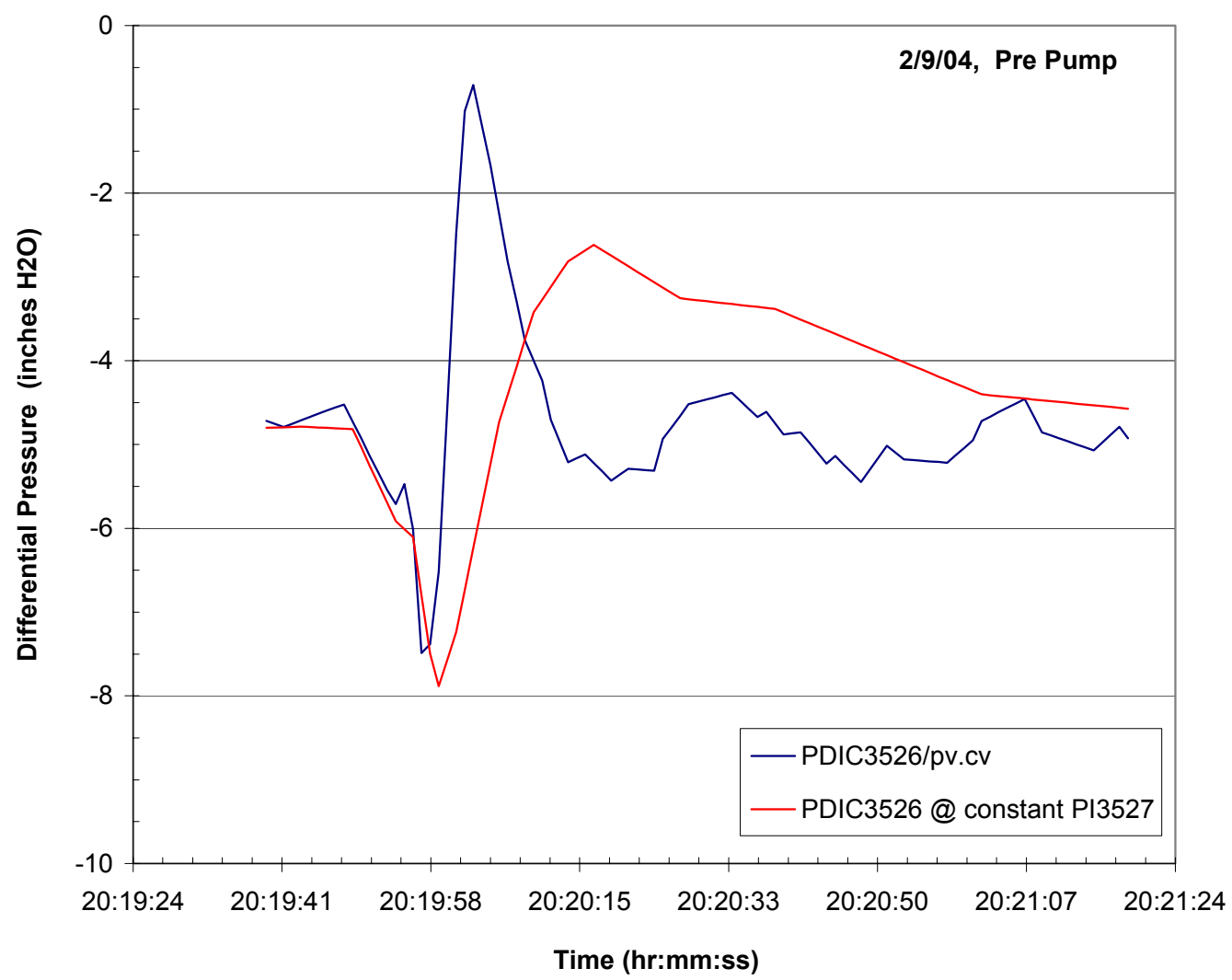

Figure 7. Comparison of Melter-Pour Spout Differential Pressures during a -2 inch $\mathrm{H}_{2} \mathrm{O}$ Surge with Current and Modified PDIC3526.

Figure 8 shows how the melter-pour spout differential pressure control loop reacts to a medium off-gas surge with a peak melter pressure of +0 inch $\mathrm{H}_{2} \mathrm{O}$ during the post glass pump operation. The measured melter-pour spout differential pressure is shown to fall immediately at the onset of surge, but the pour spout pressure (PI3527) did not begin to rise until 5 seconds later. Again, this initial drop in the differential pressure is inherent to the process due to the 5-second dead time of the PDIC3526 loop. Compared to Figure 6, the measured differential and pour spout pressures are shown to fluctuate more by \pm 5 and \pm 6 inches $\mathrm{H}_{2} \mathrm{O}$, respectively, maybe due to greater melter pressure spike for this case. Furthermore, as a result of the late PDIC3526 loop kick-in, the melter-pour spout differential pressure rose to +0 inch $\mathrm{H}_{2} \mathrm{O}$ during the recovery process, which would have stopped the pour stream momentarily.

A new melter-pour differential pressure profile during a +0 inch $\mathrm{H}_{2} \mathrm{O}$ surge was calculated under the constant pour spout pressure assumption and compared in Figure 9 with the measured profile under the current differential pressure control mode. Although the new differential pressure profile appears less oscillatory overall, the amplitudes of the two profiles are practically identical. This means that in terms of the pour rate variations there would be little difference between them. However, not shown in Figure 9 is the underlying assumption that the pour spout pressure would remain relatively constant under the new control mode, while it varied by \pm 6 inches $\mathrm{H}_{2} \mathrm{O}$ under the current differential pressure control mode. 
WSRC-TR-2004-00156

Revision 0

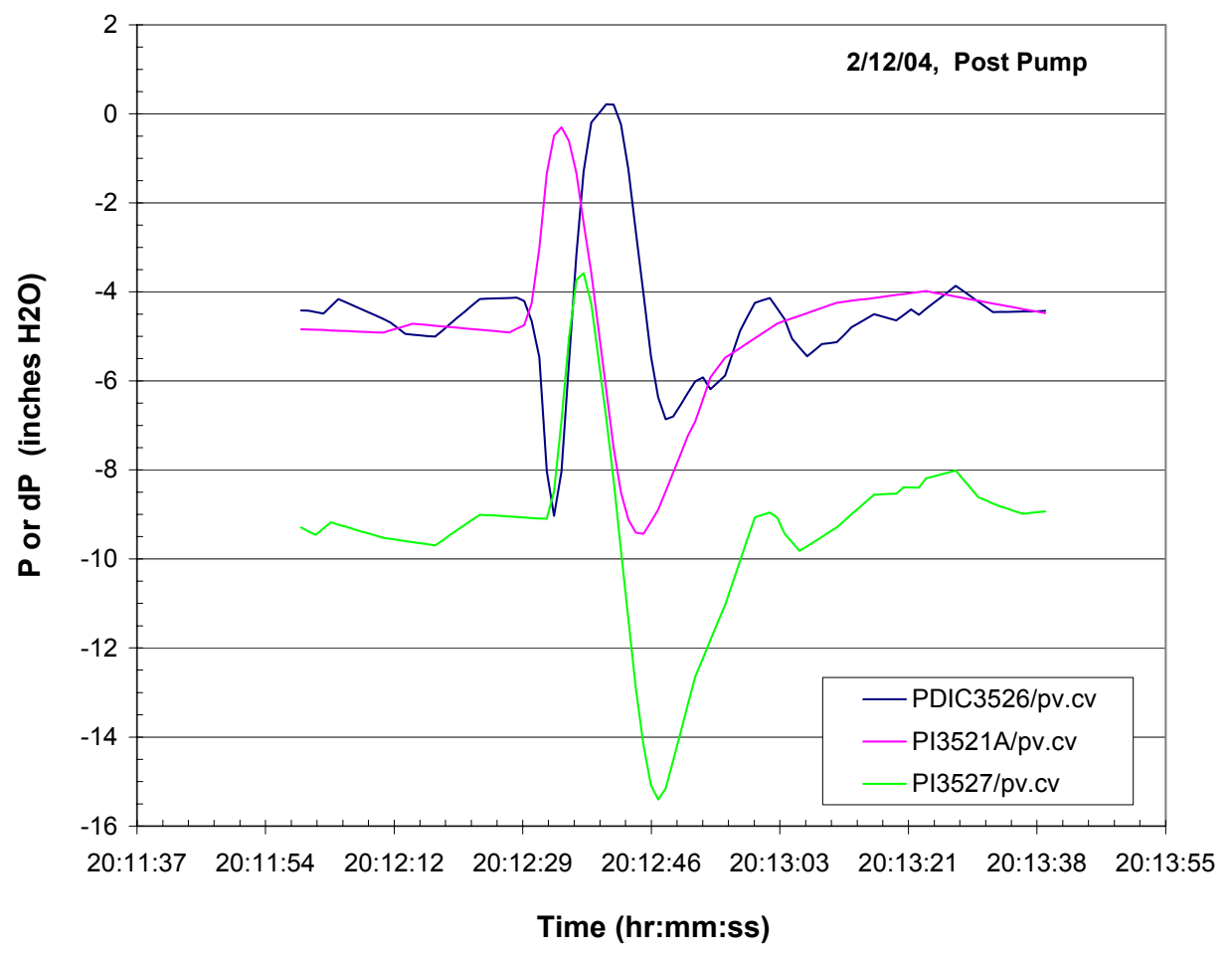

Figure 8. Melter-Pour Spout Differential Pressure Control during a +0 inch $\mathrm{H}_{2} \mathrm{O}$ Surge With Glass Pump.

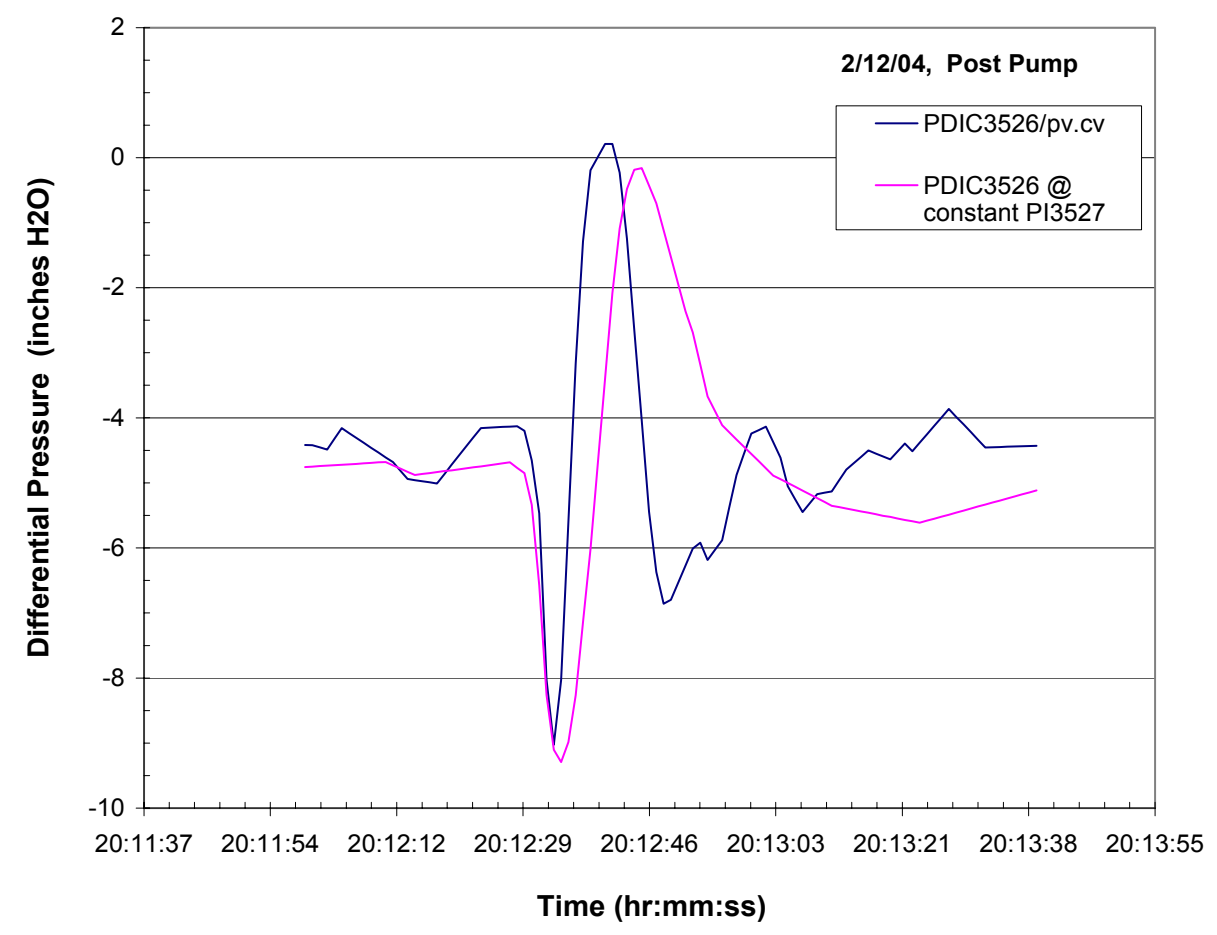

Figure 9. Comparison of Melter-Pour Spout Differential Pressures during a +0 inch $\mathrm{H}_{2} \mathrm{O}$ Surge with Current and Modified PDIC3526. 
Figure 10 shows how the melter-pour spout differential pressure control loop reacts to a large off-gas surge with a peak melter pressure near +5 inches $\mathrm{H}_{2} \mathrm{O}$ during the post glass pump operation. The measured melter-pour spout differential pressure is again shown to fall promptly at the onset of surge but, unlike in the low to medium surge cases, it peaked to +0 inch $\mathrm{H}_{2} \mathrm{O}$ twice during the recovery step. Despite the shorter PDIC3526 loop dead time of 3 seconds, the initial drop in the differential pressure was twice as large as those measured during the low to medium off-gas surges due to the excessively high surge intensity for this case. Furthermore, since the measured melter pressure profile did not show any large negative swing below its set point during the recovery step, the measured pour spout pressure profile did not show its usual negative swing either.

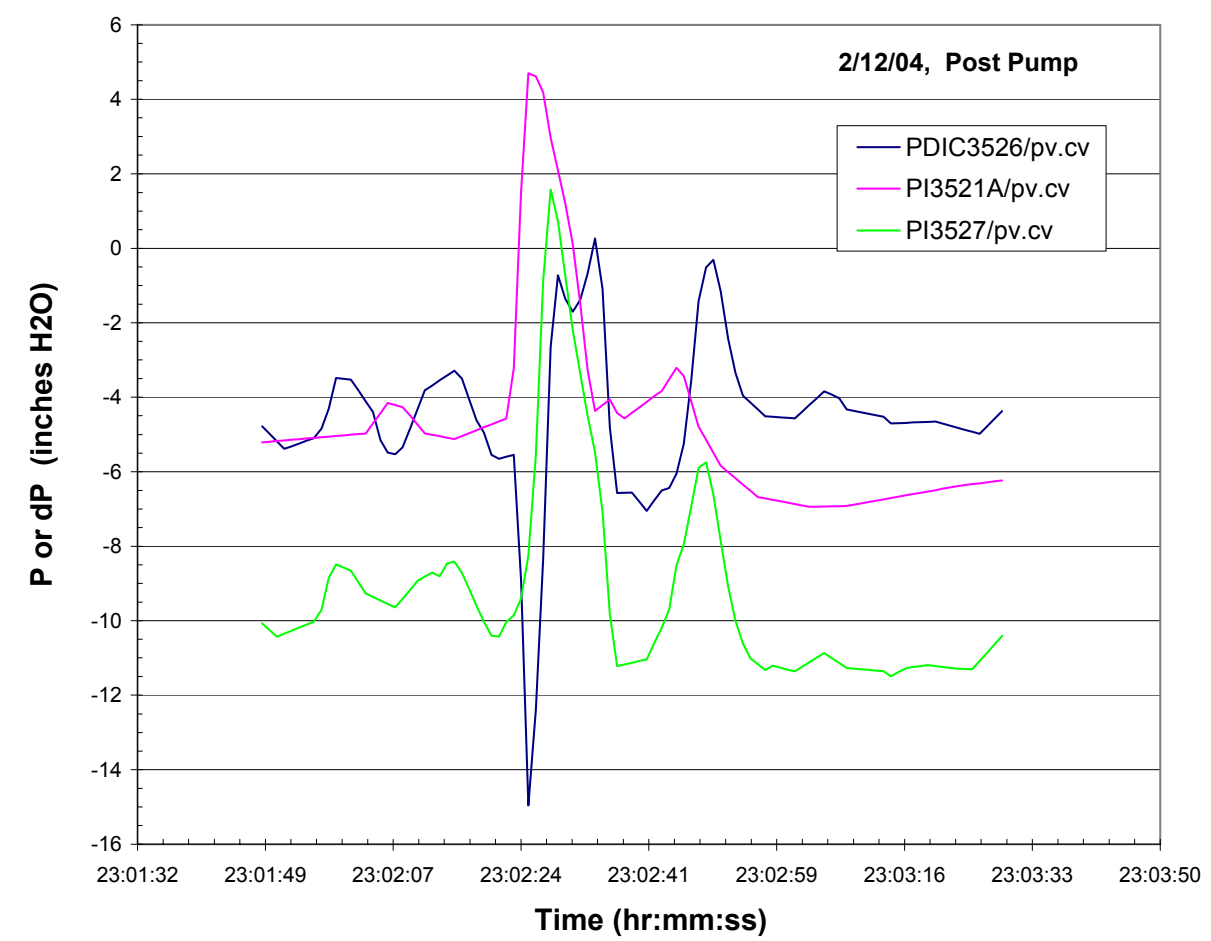

\section{Figure 10. Melter-Pour Spout Differential Pressure Control during a +5 inch $\mathrm{H}_{2} \mathrm{O}$ Surge With Glass Pump.}

A new melter-pour differential pressure profile during a +5 inch $\mathrm{H}_{2} \mathrm{O}$ surge was next calculated under the constant pour spout pressure assumption and compared in Figure 11 with the measured profile under the current differential pressure control mode. As in the low off-gas surge case, the peak value for the new differential pressure during the recovery step is considerably smaller than the measured data, which would make the pour stream less prone to waiver in case of unexpected pressure oscillations. More importantly, however, the pour spout pressure would remain as close to its predetermined set point as the new control scheme would allow, while it varied by more than 10 inches $\mathrm{H}_{2} \mathrm{O}$ in the positive direction under the current differential pressure control mode. 


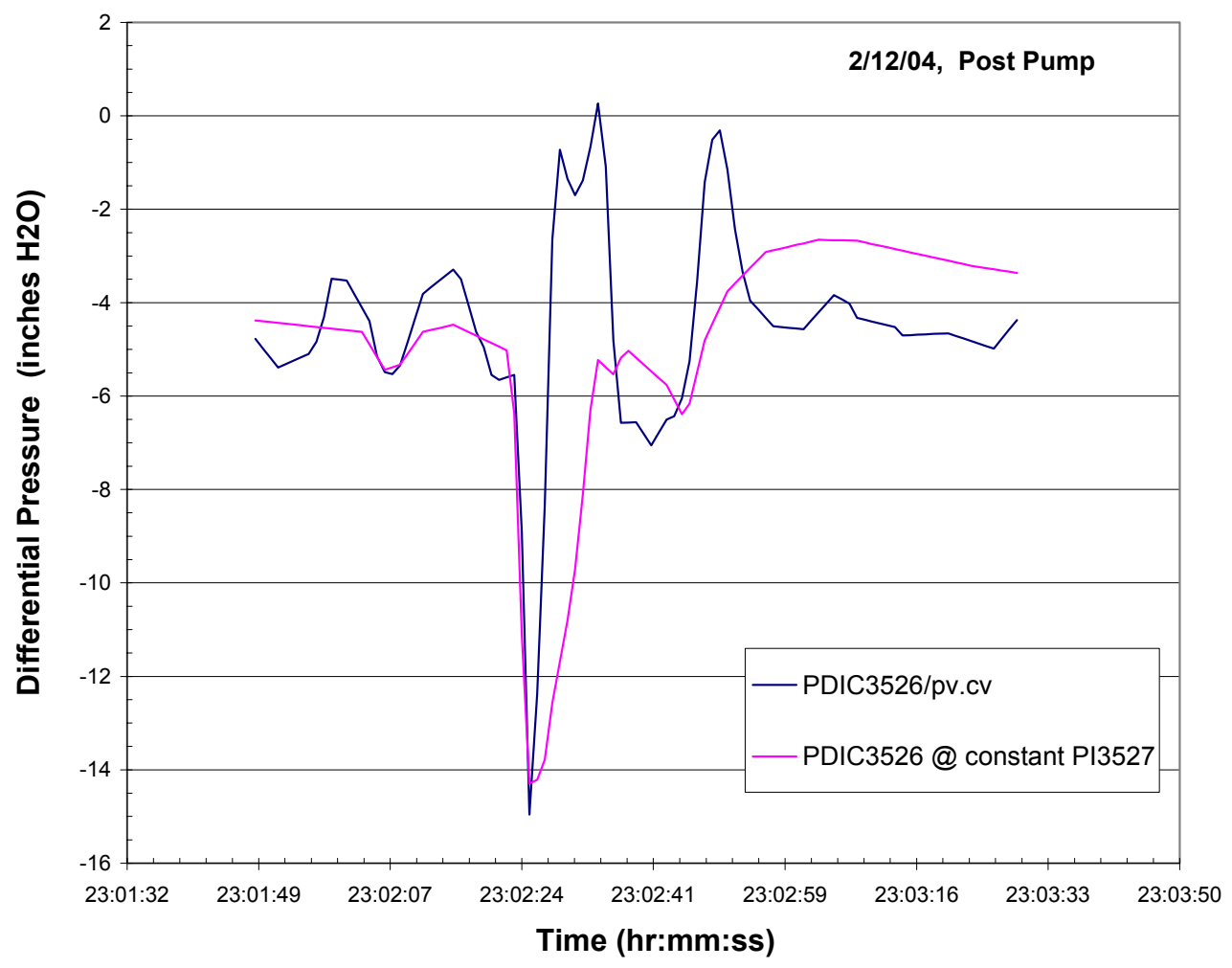

Figure 11. Comparison of Melter-Pour Spout Differential Pressures during a +4 inch $\mathrm{H}_{2} \mathrm{O}$ Surge with Current and Modified PDIC3526.

\subsection{COMPUTER SIMULATION}

In the preceding analysis, it was hypothesized that the tendency for the pour stream to waiver would depend on the amplitude of pour spout pressure fluctuations and the pour rate. This hypothesis is in line with a recent speculation that the observed pour spout pressure oscillations during the initial stages of canister filling may adversely affect melter production by causing the pour stream to waiver inside the pour spout and deposit glass inside the bellows liner. ${ }^{2}$ If it turns out that the pour spout pressure is indeed the variable to be held steady, accurate measurement of its value is essential for optimal control. In DWPF, however, the pour spout pressure is not currently measured inside the pour spout/bellows assembly. Instead, it is measured inside a 2inch pipe leading to the spout jet at a location several feet downstream of the pour spout control air entry point. The ideal location for the pressure transmitter (PDT3527) would be upstream of the control air entry point as close to the pour spout as practically possible, if not within the pour spout/bellows assembly. The actual pressure inside the bellows was measured recently using a portable pressure gauge and the readings were generally $\sim 1$ inch $\mathrm{H}_{2} \mathrm{O}$ higher than the data taken at the current PDT3527 location during a steady state. However, it remained uncertain whether the melter-pour spout differential pressure with the current PDT3527 input would fluctuate more during a transient than it would with the PDT3527 placed ideally, thereby adversely affecting the pour stream. The aim of computer simulation was to resolve this uncertainty using the existing off-gas dynamics model. 


\subsection{Model Input}

The existing off-gas dynamics model was revised so that the action of the PDIC3526 loop could be simulated off both the current and ideal PDT3527 locations. The revised model was then run to simulate an off-gas surge as the reference transient event, when the PDIC3526 loop was fed with the two different PDT3527 inputs. The baseline data used in the model runs were the steady state data taken on $6 / 19 / 03$ just prior to the +0.4 inch $\mathrm{H}_{2} \mathrm{O}$ surge at 03:30 hour. At that time, the melter was being fed with the SB2 feed at 0.475 GPM. The resulting steady state model predictions are compared with the corresponding DCS data in Table $2 .{ }^{1}$

One key assumption made in the model input was that the pressure drop between the pour spout and the current PDT3527 location several feet downstream was 1 inch $\mathrm{H}_{2} \mathrm{O}$ based on the recent measurement of the actual pour spout pressure using a portable pressure gauge. As determined earlier for the medium off-gas surge, the PDIC3526 loop dead time was assumed to be 5 seconds (Table 1).

Table 2. Comparison of DCS Data and Model Output for 6/19/03 Melter Run.

\begin{tabular}{||l|c|c||}
\hline \multicolumn{1}{|c|}{ Process Parameters } & Data & Model \\
\hline Melter Pressure, PIC3521 (“wc) & -5.09 & -4.96 \\
\hline Melter Vapor Space Temperature, TI4085D ( $\left.{ }^{\circ} \mathrm{C}\right)$ & 727.4 & $\mathrm{n} / \mathrm{a}$ \\
\hline Melter Vapor Space Gas Temperature ( $\left.{ }^{\circ} \mathrm{C}\right)$ & $\mathrm{n} / \mathrm{a}$ & 520.2 \\
\hline Melter Air Inleakage (lb/hr) & $\mathrm{n} / \mathrm{a}$ & 50.3 \\
\hline Air Purge to Backup Film Cooler, FIC3221B (lb/hr) & 339.6 & 340.0 \\
\hline Total Melter Air Purge, FIC3221A (lb/hr) & $1,066.7$ & 1,040 \\
\hline Off-Gas Temp. at Film Cooler Exit, TIC3682 ( $\left.{ }^{\circ} \mathrm{C}\right)$ & 314.2 & 315.8 \\
\hline Melter Pressure Control Air, FIC3691 (lb/hr) & 494.6 & 498.2 \\
\hline Pressure Drop across Off-Gas Header, PDI3684 (“wc) & 0.83 & 0.74 \\
\hline Off-Gas Condensate Tank Pressure, PI3485A (“wc) & -3.8 & -3.5 \\
\hline OGCT Air Inleakage (lb/hr) & $\mathrm{n} / \mathrm{a}$ & 26.7 \\
\hline Pressure Drop across SAS's, PDI3387 (“wc) & 18.8 & 20.5 \\
\hline$\Delta$ P across Condenser/De-Ent., PDI3389/3384 (“"wc) & 3.4 & 3.9 \\
\hline Pressure Drop across HEME, PDI3411 (“wc) & 6.0 & 5.5 \\
\hline Pressure Drop across HEPA, PDI3400 (“wc) & 0.8 & 0.8 \\
\hline Off-Gas Flow to HEPA, FI3401 (lb/hr) & 1,770 & 1,722 \\
\hline Pressure Drop across Exhauster, PDI3582 (“wc) & -39.0 & -33.7 \\
\hline Air Inleakage at Exhauster (lb/hr) & $\mathrm{n} / \mathrm{a}$ & 1,003 \\
\hline Exhauster Speed, SIC3585 (rpm) & 818 & 814 \\
\hline Pour Spout Pressure, PI3527 (“wc) & -12.0 & -12.0 \\
\hline Pour Spout Pressure Control Air, FI3526 (lb/hr) & 51.0 & 53.7 \\
\hline Pour Spout Air Inleakage (lb/hr) & $\mathrm{n} / \mathrm{a}$ & 60.2 \\
\hline \hline
\end{tabular}

$\mathrm{n} / \mathrm{a}=$ not applicable or available. 


\subsection{Model Results}

Figure 12 shows the calculated profiles of melter pressure, control air flow, and exhauster speed throughout the duration of the +0.4 inch $\mathrm{H}_{2} \mathrm{O}$ surge that lasted less than 15 seconds. It is noted that the peak melter pressure predicted by the model is slightly higher at near +1 inch $\mathrm{H}_{2} \mathrm{O}$. The cold cap off-gas flow profile shown is the sum of both condensable and non condensable flows based on the estimated surge intensities of $11 \mathrm{X}$ and $12 \mathrm{X}$ nominal, respectively, at the nominal feed rate of 0.475 GPM. ${ }^{1}$ The resulting melter pressure profile shown constituted one of the inputs for the PDIC3526 loop.
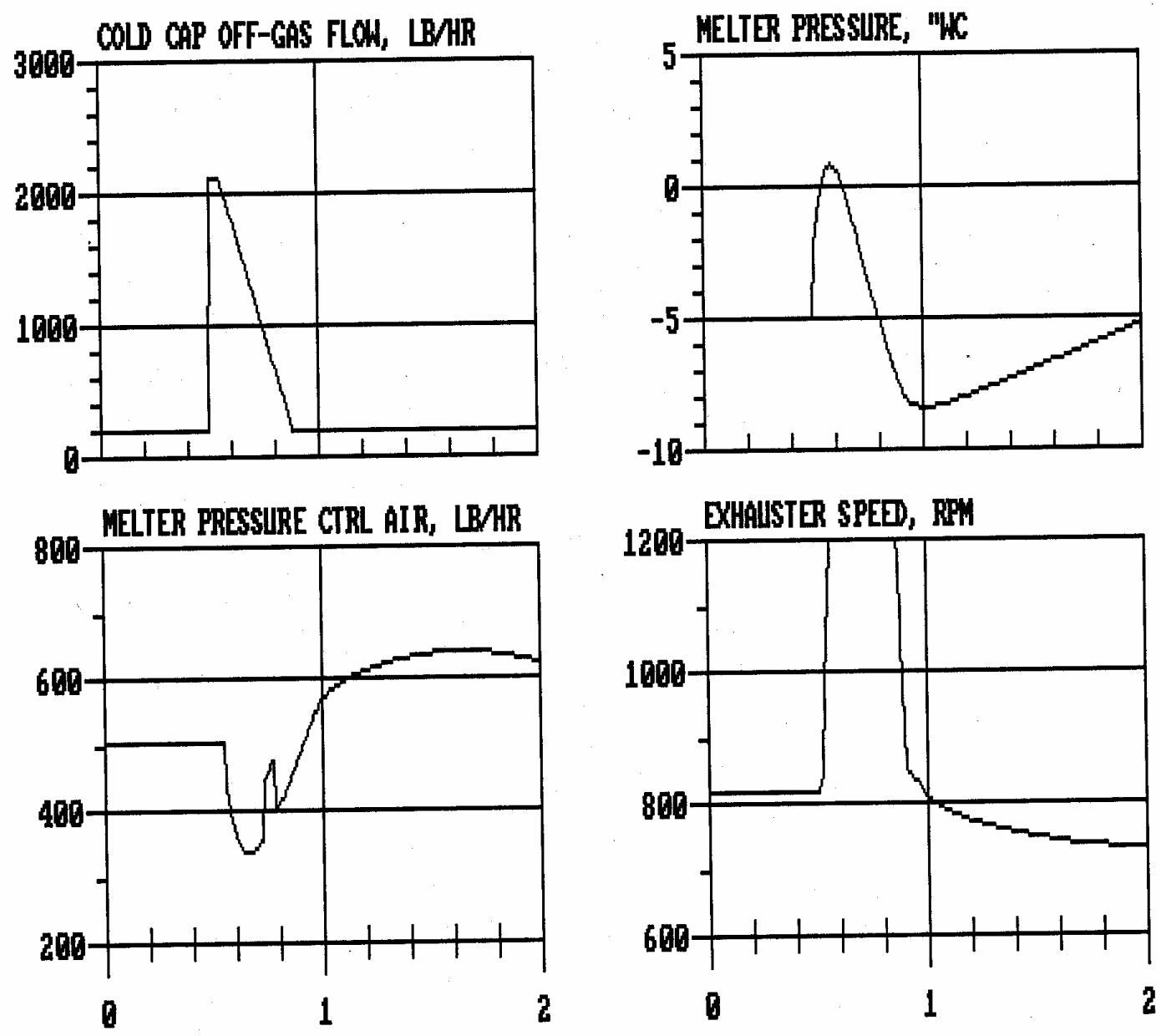

TINE IN MINUTES

Figure 12. Calculated Profiles of PIC3521, FIC3691 and SIC3585 During +0.4 inch $\mathrm{H}_{2} \mathrm{O}$ Off-Gas Surge on 6/19/03. 
The calculated differential pressures between the melter and the pour spout (PS) and between the melter and the current PDT3527 location, which is near the spout jet (SJ), are compared in Figure 13 when the PDIC3526 loop was fed with the reading taken at the current PDT3527 location. Since the measured pressure at the current PDT3527 location was -12 inches $\mathrm{H}_{2} \mathrm{O}$, as shown in Table 2, the differential pressure between the melter and the current PDT3527 location was -7 inches $\mathrm{H}_{2} \mathrm{O}$ initially, while that between the melter and the pour spout is shown to be -6 inches $\mathrm{H}_{2} \mathrm{O}$ due to the assumed pressure drop of +1 inch $\mathrm{H}_{2} \mathrm{O}$ between the pour spout and the current PDT 3527 location. At the onset of surge, both differential pressures are shown to fall immediately, just as the measured melter-spout jet differential pressures did in Figure 6 through Figure 11. The two differential pressures are then shown to reach their respective minima and maxima at the same time, while more or less maintaining the 1 inch $\mathrm{H}_{2} \mathrm{O}$ pressure difference between them as they did initially.

The same two differential pressure profiles as shown in Figure 13 were recalculated next by assuming that the PDT3527 transmitter was located inside the pour spout, and the true pour spout pressure reading was fed to the PDIC3526 loop. The resulting profiles shown in Figure 14 are in essence identical to those in Figure 13 except that the entire profiles of both differential pressures are now shifted down by 1 inch $\mathrm{H}_{2} \mathrm{O}$. This is because the set point of the PDIC3526 loop was fixed at -7 inches $\mathrm{H}_{2} \mathrm{O}$ in both cases.

The calculated profiles of the pour spout and melter-pour spout differential pressures are shown together in Figure 15 when the PDIC3526 loop was fed with the reading taken at the current PDT3527 location. The initial pour spout pressure is shown to be -11 inches $\mathrm{H}_{2} \mathrm{O}$ due to the assumed pressure drop of 1 inch $\mathrm{H}_{2} \mathrm{O}$ between the pour spout and the current PDT 3527 location. The calculated pour spout pressure fluctuated from -17 to -10 inches $\mathrm{H}_{2} \mathrm{O}$ for the total amplitude of 7 inches $\mathrm{H}_{2} \mathrm{O}$, while the calculated melter-pour spout differential pressure fluctuated from -12 to -3 inches $\mathrm{H}_{2} \mathrm{O}$ for the total amplitude of 9 inches $\mathrm{H}_{2} \mathrm{O}$.

The calculated pour spout and melter-pour spout differential pressures with the assumption that the PDT3527 transmitter was located inside the pour spout are shown in Figure 16. Again, both pressure profiles are identical to those in Figure 15, including the amplitudes of fluctuations, except that they are now shifted down by 1 inch $\mathrm{H}_{2} \mathrm{O}$. As stated earlier, the pour rate is directly proportional to the melter-pour spout differential pressure, and the major factors affecting the pour stream waiver from the DSC control standpoint are likely to be the amplitude of pour spout pressure fluctuations and the pour rate. It can, therefore, be concluded from the results shown in Figure 15 and Figure 16 that the differential pressure control based on the current PDT3527 location is not likely to adversely impact the pouring operation more so than when the PDT3527 is located inside the pour spout. 
WSRC-TR-2004-00156

Revision 0

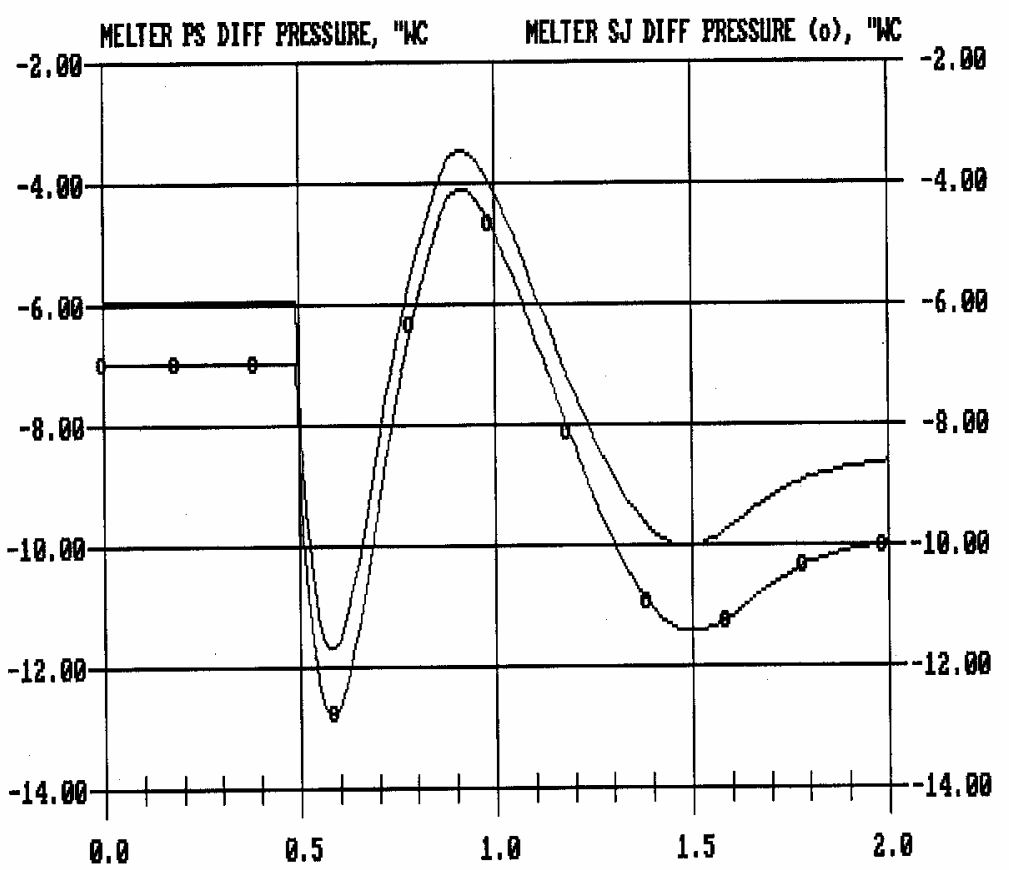

TIME IN MIMUTES

Figure 13. Calculated Differential Pressure Profiles With Current PDT3527 Input.

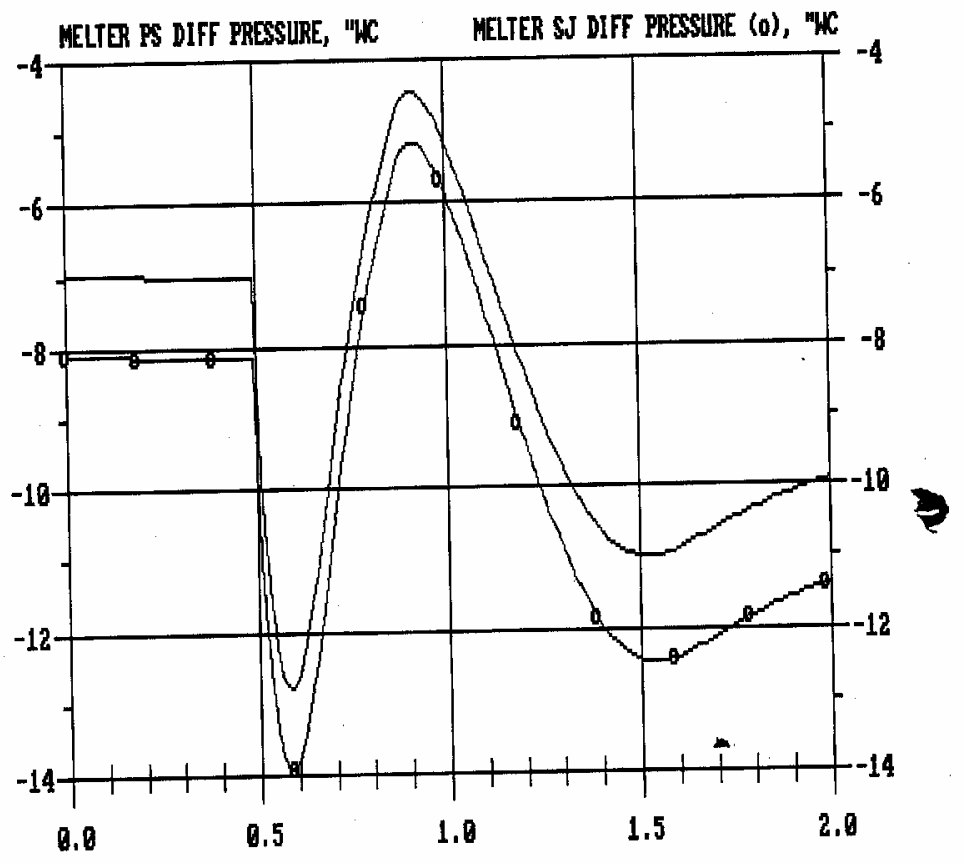

TIME IN MINUTES

Figure 14. Calculated Differential Pressure Profiles With Revised PDT3527 Input. 
WSRC-TR-2004-00156

Revision 0

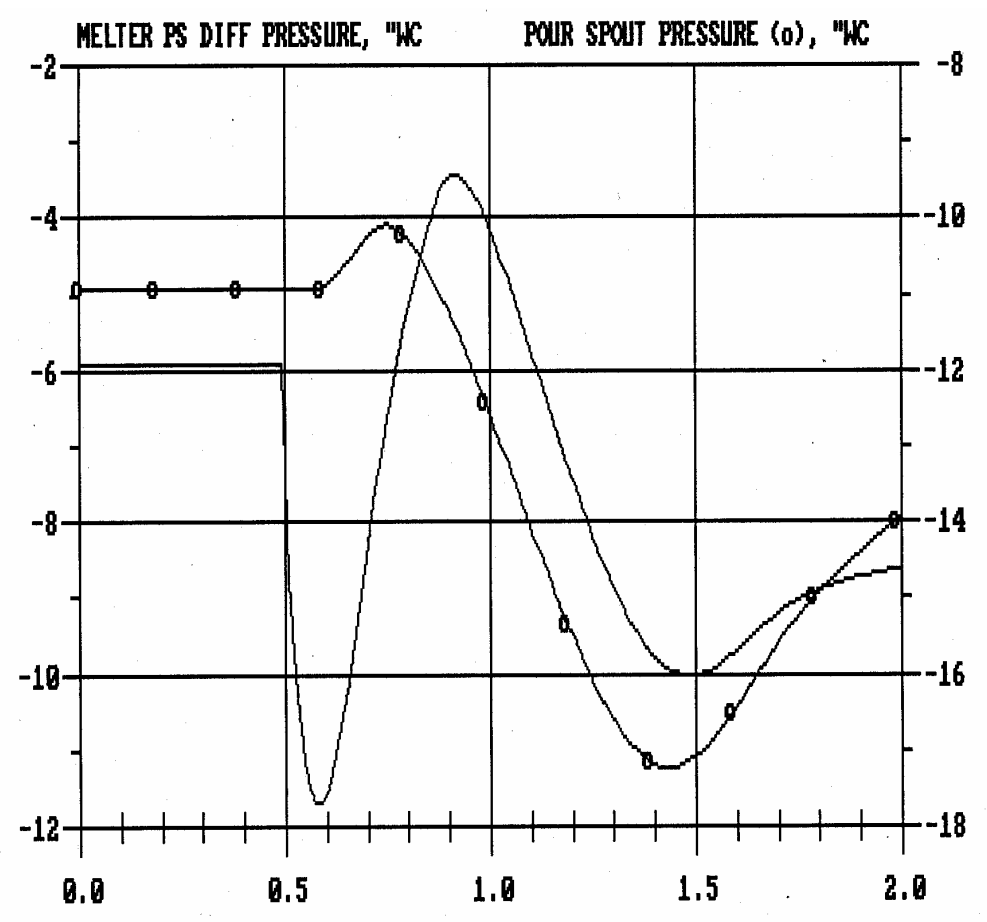

TIME IN MINUTES

Figure 15. Calculated Profiles of Differential and Pour Spout Pressures with Current PDT3527 Input.

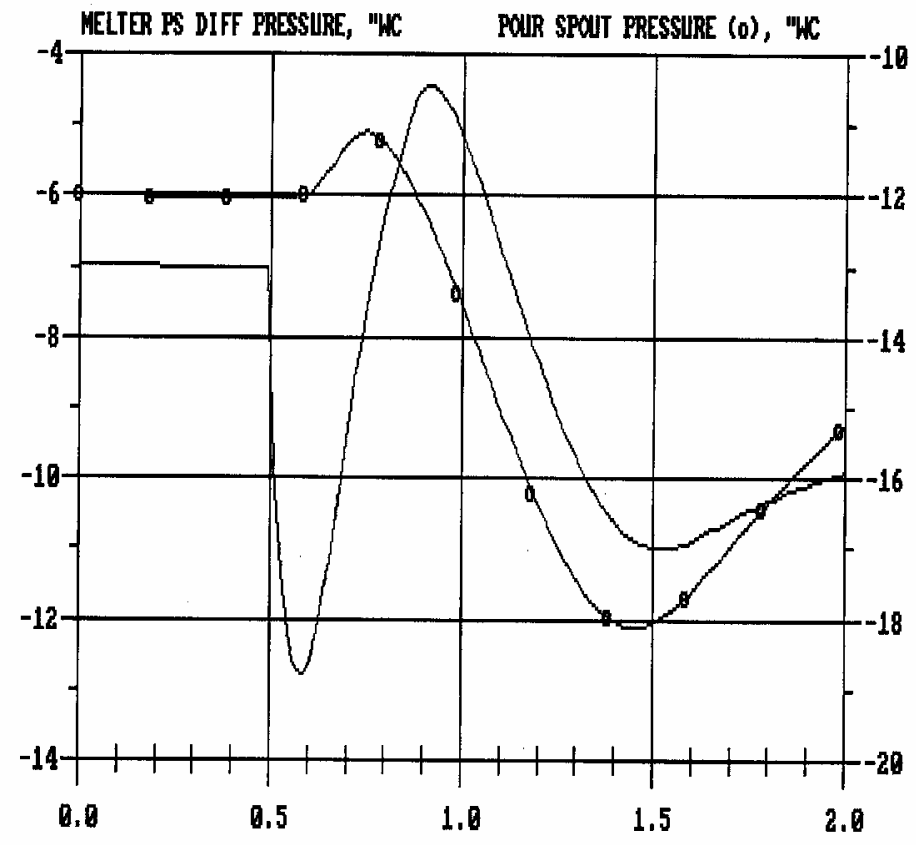

TIME IN MINUTES

Figure 16. Calculated Profiles of Differential and Pour Spout Pressures with Revised PDT3527 Input. 


\subsection{CONCLUSIONS}

The DCS off-gas data collected in parallel with the glass pump evaluation efforts were analyzed in regards to the performance of three critical control loops in attenuating the impacts of off-gas surges on the melter and melter-pour spout differential pressure spikes. Based on the results of data analysis, the following conclusions could be drawn:

- The intensity of off-gas surging and subsequent pressure spikes appeared to have gotten higher with the glass pump in operation than without the glass pump.

- The measured dead times of the PIC3521, FIC3691 and PDIC3526 loops in response to the off-gas surges of small, medium and large intensities ranged from 2 to 6 seconds.

- These inherent dead times represent a significant setback for controlling off-gas surges that typically last for 5 to 10 seconds. Especially, delayed responses by the FIC3691 and PDIC3526 loops were actually making the recovery process more difficult.

- The feed forward control is not a viable option for mitigating pressure spikes, since offgas surging neither can be measured nor predicted; only its impact can be measured as the PI3521.

The results of computer simulation runs further showed that throughout the duration of off-gas surge the amplitudes of fluctuations in both the melter-pour spout differential pressure and the pour spout pressure were in essence independent of the PDT3527 location, which confirmed that the differential pressure control based on the current PDT3527 location is not likely to adversely impact the pouring operation more so than when the PDT3527 is located inside the pour spout/bellows assembly. 


\subsection{RECOMMENDATIONS/PATH FORWARD}

Based on the results of data review and analysis, it was hypothesized that maintaining as small fluctuations as possible not only in the melter-pour spout differential pressure (PDI3526) but the pour spout pressure (PI3527) itself would be crucial to minimizing the pour stream waiver and thus lengthening the duration between successive pour spout cleanouts. It is, therefore, proposed that the following changes be made to the current off-gas control strategy:

- Rely exclusively on the PIC3521 loop for the control of off-gas surges.

- Detune the FIC3691 loop to avoid excessive melter pressure oscillations during the recovery process; its implementation is currently underway. ${ }^{4}$

- To attenuate the intensity of pressure spikes, look for ways to reduce the dead time of the PIC3521 loop.

- Increase the FIC3691 set point from its current value of 500 to $\sim 800 \mathrm{lb} / \mathrm{hr}$ mainly for the attenuation of large melter pressure spikes above +2 inches $\mathrm{H}_{2} \mathrm{O}$.

- Discontinue the current melter-pour spout differential pressure control by decoupling the PT3521 from the PDIC3526 loop.

- Instead control the pour spout pressure (PI3527) at the predetermined set points for the pouring and non pouring operations by modulating the pour spout control air valve.

- Perform a detailed simulation study using the existing off-gas model to identify the exact causes for the pour spout pressure oscillations that occur during the initial stages of canister filling. 


\subsection{REFERENCES}

1. Choi, A. S., "Preliminary Results of Dynamic Off-Gas Surge Analysis,"

SRT-PDH-2003-00015, Westinghouse Savannah River Co., Aiken, SC 29808 (2003).

2. Miller, M. S., and Iaukea, J. F., "Path Forward: Melter Control Team Recommendations

(U)," CBU-WSE-2003-00188, Westinghouse Savannah River Co., Aiken, SC 29808 (2003).

3. Buch, V. R., Private Communication, DWPF Process Cognizant Engineering, May 11, 2004.

4. Coleman, J. R., Private Communication, DWPF Process Control Engineering, May 27, 2004 